\title{
Rehabilitation of unstable knee in osteoarthritis
}

\author{
CRISTEA Florentina ${ }^{1,}$, GHERGHEL Robert ${ }^{2,3}$, ONU Ilie $^{2,3}$
}

Corresponding Author: Ilie Onu, E-mail: $\underline{\text { ilie.onu@tuiasi.ro }}$

\section{Faculty of Physical Education and Sport, "Dunarea de Jos" University of Galati, Romania \\ 2. Department of Biomedical Sciences, Faculty of Medical Bioengineering, \\ University of Medicine and Pharmacy "Grigore T. Popa" Iasi, Romania \\ 3. Micromedica Medical Clinic, departments of orthopedics and physiotherapy, Piatra Neamt}

\begin{abstract}
Knee instability is a common condition found in degenerative knee osteoarthritis. The evolution of the disease is a chronic one, with acute exacerbations that accentuate the static and dynamic deterioration of the knee joint. Women are more susceptible in $70 \%-80 \%$ of cases, with an increased frequency after menopause, between 40 to 70 years, being often associated with obesity and varicose veins. Starting from these data and then extrapolating with the increased number of people coming to treatment with this condition, we considered that a more in-depth study theoretically, but especially practical, in terms of the effectiveness of physiotherapy treatment is slowing down the evolution of the disease. Based on the objectives we presented earlier, we are determined to focus our efforts on this category of patients, and through our study we try to find new ways to reduce the suffering of the patients and to ensure the sustainability of the obtained results.
\end{abstract}

Key words: knee osteoarthritis, physiotherapy, rehabilitation, instability, muscle toning,

\section{Introduction}

Knee Osteoarthritis (KOA) is a degenerative condition that consists in the destruction of the hyaline cartilage, find on the articular bone extremities $(1,2,3)$. Recent studies have shown that osteoarthritis is not limited to the destruction of hyaline cartilage, but affects the entire joint, including the subchondral bone $(4,5)$. There is a progressive wear of the articular cartilage, which loses an amount of flexibility, the pain will appear and the mobility of the knee will be limited $(6,7)$. The knee joint is not only the largest, but also the most complex joint of the human body $(8,9)$. Knee joint is able to withstand stress and injury risks in all daily activities, as well as in various grades or sports activities $(10,11)$. However, people with anatomical problems such as curved legs may experience pain. Normal processes related to aging and overweight, as well as post-traumatic conditions, can lead to joint wear $(12,13,14)$.

Frequency of axial deviations in the frontal plane, the degree of physical disability, especially in the advanced stages, the diminished autonomy of the affected persons, as well as the risk to which the person is subjected, in the case of the inproper treatment of KOA and in the case of not practicing physiotherapy programs, determined us to organize the research in this conditions $(15,16)$. Functional physiotherapy recovery is the main means of medical recovery assistance (17). Its primary objective is to restore the function (lost or deficient) or to obtain a major improvement (or finding compensatory mechanisms) (18)

Research objectives: Highlighting the deficiencies that accompany KOA on all levels on the sample subjects, trying to confirm and add to the ones provided from the medical surces. Identification and selection of the most appropriate methods, procedures and techniques, witch can optimize the recovery of patients, according to the particularities of each subject.

Structuring and restructuring the recovery program determined by the behavior of the subjects and the results of the periodic evaluation it is an another objective. 
Research tasks: formulation of working hypotheses; establishing the working modalities; selection of the group subjects, and choosing the most efficient techniques, methods and procedures according to the particularities of each subject.

\section{Hypotheses}

Physical medicine possesses the necessary means to reduce the pain and inflammation and prevents disabling deformities (19). The methodological principles of physiotherapy, positively influence the degree of mobility in KOA, and patients witch are following a functional recovery scheme can be socially and / or professionally recovered (20). Medical recovery through physiotherapy is based on modern therapeutic concepts, its efficiency being directly proportional to the shortening of the healing time (21). In the case of definitive morphological or functional lesions, physiotherapy ensures the formation of compensatory mechanisms (22). Physiotherapy objectives are strictly related to the symptoms that are frequently repeated in the KOA, even if they arent present at the time of treatment (23). Physiotherapy in KOA is performed individually or in small groups of patients with the same symptoms (24).

\section{Methods and materials:}

a) Theoretical documentation;

b) Method of investigation;

c) Observation:

d) Method of measurement (exploration and evaluation);

e) Data recording, processing and graphical representation.

All the techniques used in the treatment scheme must start from a positive diagnosis, accompanied by a clinical picture and objective investigations. The functional balance, the current state and the presumptive prognosis of the evolution of the deficit must be established, then the immediate and longterm goals will follow (26). The examination includes: anamnesic data, clinical and paraclinical examination of the patient and specific tests to establish the positive diagnosis of $\operatorname{KOA}(17,18)$. This assessment will be initial and periodic in order to follow the evolution of recovery. The collected data are quantified and noted in the treatment records. The examination includes: anamnesis; somatoscopic examination; palpation; joint balance; muscle testing; examination of static and dynamics; global (appreciation of locomotion) $(19,20)$. The study was carried out in the Center for Physical Therapy within the Faculty of Physical Education and Sports of the "Dunărea de Jos" University in Galați, with the support of the physiotherapy and orthopedics department of the Micromedica Clinic from Piatra Neamt. The equipment of the physiotherapy room is as follows: wall bracket, physiotherapy table, gym bench, mattresses, sand bags, electrotherapy equipment, stepper, ergometric bicycle, dumbbells, rollers, elastic bands, Rocker cage, ultrasound, mechanical elongation, table shochwave apparatus, etc. For the exploration and evaluation of patients we use goniometers, metric tape, scales, special records methods for recording the collected data.

For the research I selected twelve subjects that entered the treatment between October 2018 - March 2019. In the first stage of research an theoretical documentary was made, by studying the specialized literature and I got in touch with specialists in the field of recovery (medical doctor and physiotherapist). In the second stage I selected the subjects and I formed the group for the study and I prepared the materials for testing and treatment. In the third stage we developed and applied the physiotherapy programs in order to recover the patients after an individual evaluation. On the final stage I appreciated the dynamic evolution of the parameters, and I collected and interpreted the obtained data, using an graphically processed method. After that I carried out this study on a group of 12 patients, with age between 40 and 74 years old, who had unilateral or bilateral KOA. Left KOA was found on 4 subjects, right KOA on 3 of them, and 5 patients showed bilateral involvement.

The physiotherapy program was personalized and aimed at achieving the proposed goals of the recovery. The physiotherapeutic treatment plan includes: regaining quadriceps muscle strength, as extensor and "locker" of the knee; the recovery of the quadriceps as a stabilizer in the critical stability zone between $60^{\circ}-90^{\circ}$; increasing the tone of the hamstrings is done at the $15^{\circ}-20^{\circ}$ end of extension; train the tensor fasciae latae and the sural triceps. Restoring knee joint mobility to gain normal function is another important goal, in addition to stability and strength, and is always done in parallel $(11,13,14)$.

The physiotherapy techniques used in program was mobilizations of the patella in transverse and 
longitudinal plane (21); posture for the reduction of knee flexion: the patient in the ventral decubitus, with the leg outside the table, with a sandbag below the knee. Sitting on one chair with one leg extended to another chair, weights are applied to the knees (22); autopassive and active exercises with their own body weight and with diferent weights (23); facilitation techniques (24).

Physiotherapy is assisted by other procedures with the role of increasing soft tissue elasticity, reducing muscular contractions and retractions, such as: local ice massage; short waves with pulses in athermic dosage; low frequency currents, medium frequency interference currents or using excitomotor forms;

LASER; aimed procedures for improving the vascularization and the local tissue trophicity, diathermy, low frequency electromagnetic fields; the massage plays a major role right from the beginning of the recovery program thanks to its favorable effect on stimulating proprioception (maintaining muscle tone) and by mobilizing the patella on the femoral condyles. In addition, the local tissue circulatory and biotrophic effect cannot be neglected. To these physical procedures was added our physiotherapy program, which contained a total of 22 exercises, using personalized dosing and breaks between exercises; with these we reached the goals set initially and presented previously (22-25).

\section{Results}

After the recovery programs were applied proceed to the next step: the collection, processing and interpretation of the data obtained in order to confirm or disprove the working hypothesis. We used several parameters specific to the research methodology, namely: amplitude, arithmetic mean, standard deviation and coefficient of variation. The standard deviation is a measure of the dispersion of values around a value considered medium. The coefficient of variation is an indicator of the dispersion of the values in the series that are expressed as a percentage (27).

Following the calculations we have come to the conclusion that the values we have obtained support the hypothesis that physiotherapy positively influences the mobility of patients with KOA.

This can be found in the graphical representations from the following graphics.

\section{Discutions}

Following the study and analyzing the obtained results, we reached the following discutions. The recovery program applied to patients with KOA gave favorable results in terms of knee mobility, flexion and extension. Following the application of the physiotherapy program, a considerable improvement was observed in the muscles of the lower limbs. The program is more effective when the patient participates actively and consciously and respects the indications and contraindications received from the physical therapist. In order to maintain the results obtained, patients with KOA must continue the recovery program for the rest of their lives, at home or in special centers, depending on the stage of the disease. By observing the fundamental principles of physiotherapy: the principle of grading the effort, the principle of effective dosing, the principle of individualizing the treatment, the principle of the precociousness of the treatment, favorable results were obtained. Overweight influences the appearance of KOA. The reintegration of people with KOA into socio-daily activities was achieved by applying the appropriate recovery program

\section{Conclusions}

From the statistical analysis of the data obtained from the initial and final parameters measurements obtained, the knee angles of the patients included in the study showed significant changes. The physiotherapeutic treatment had positive effects on the knee range of motion, both in flexion and in extension, fact demonstrated by the parameters obtained at the final evaluation. The initial flexion and extension parameters, were changed after the recovery treatment by physiotherapy, so that the final parameters approached the reference ones. The normalization of the biomechanical function of the knee was the result of this study, thus contributing to the generation of a protocol that aims to make the recovery programs effective by physiotherapy. We consider that the results obtained make a qualitative contribution of the physiotherapeutic program, by reducing the working time, and costs of the treatment sessions. The rehabilitation of the osteoarthritic knee instability should be carried out in an efficient manner, targeted and adapted to each patient, in order to obtain the reduction of functional and algic symptoms, based on clear and easy to apply programs and protocols. 


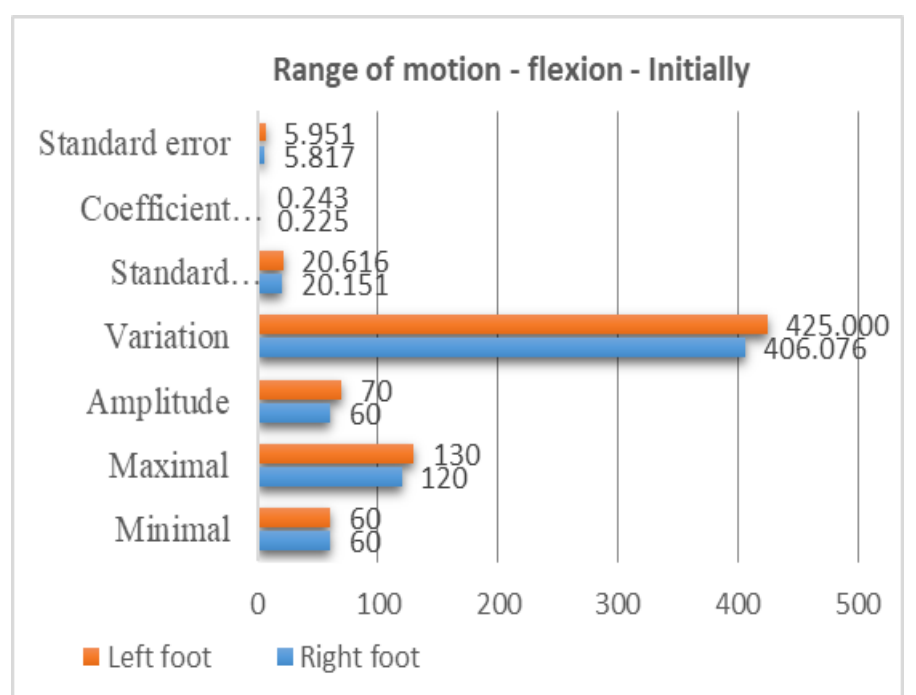

Fig.1 Dispersion parameters calculation for the range of motion flexion initially

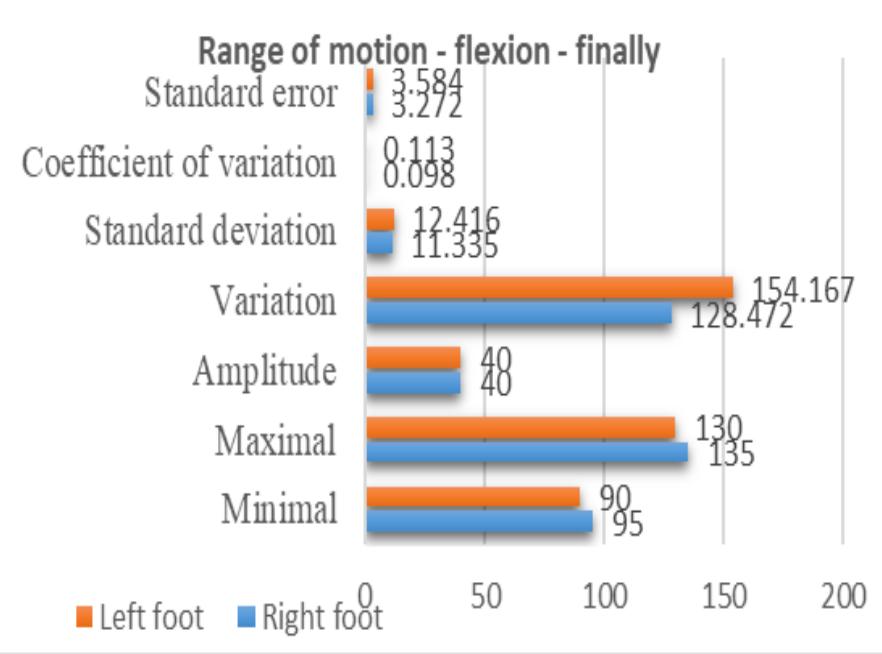

Fig.2 Dispersion parameters calculation for the range of motion flexion finally

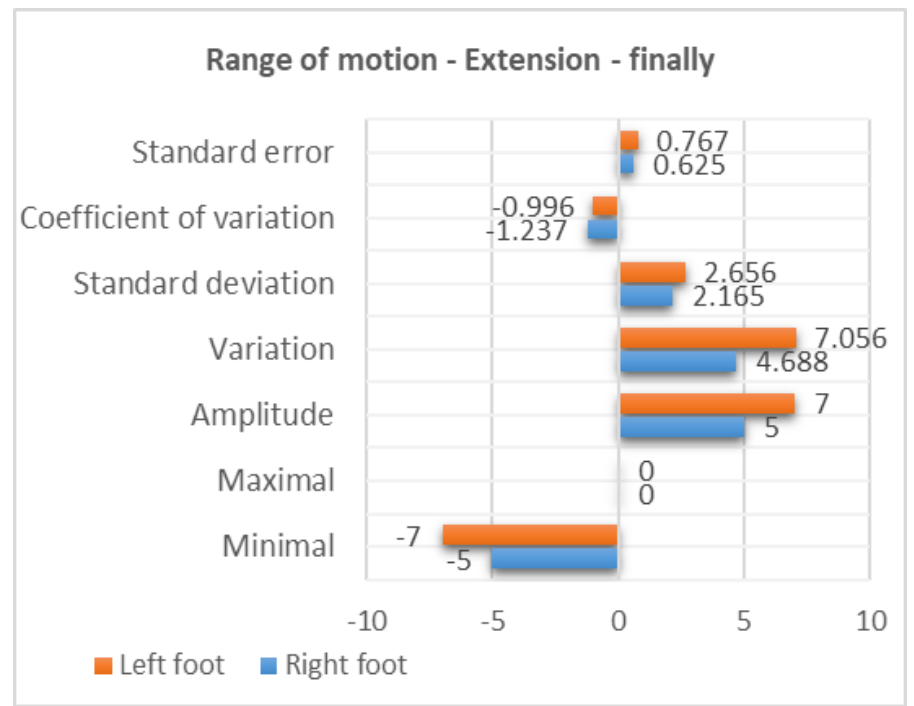

Fig.3 Dispersion parameters calculation for the range of motion extension initially

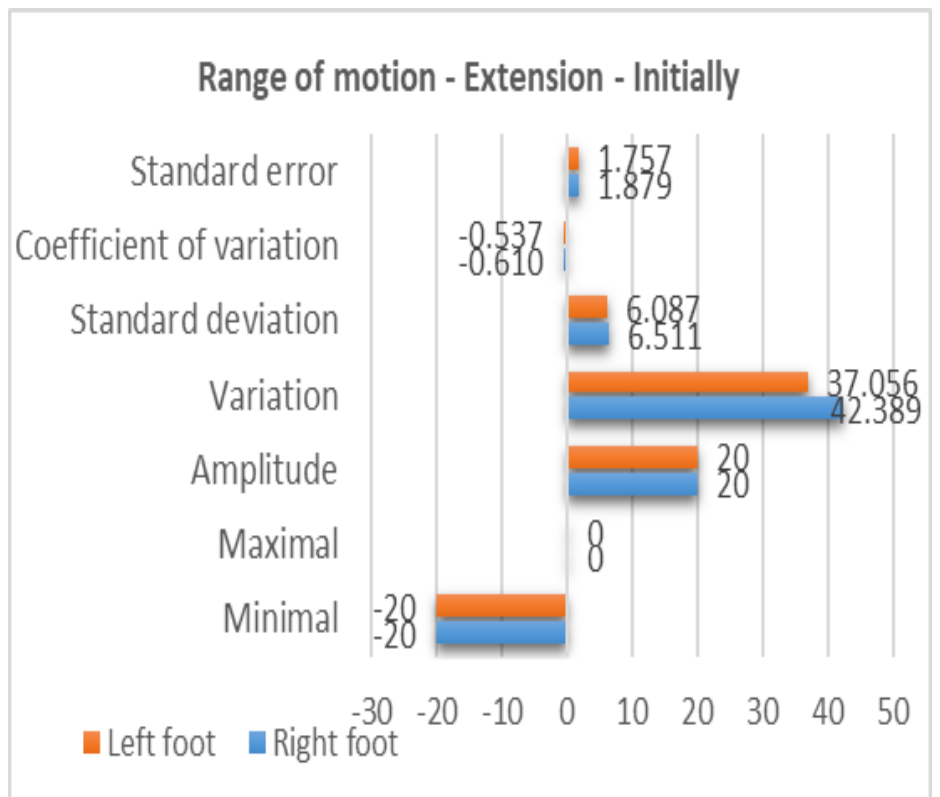

Fig.4 Dispersion parameters calculation for the range of motion extension finally

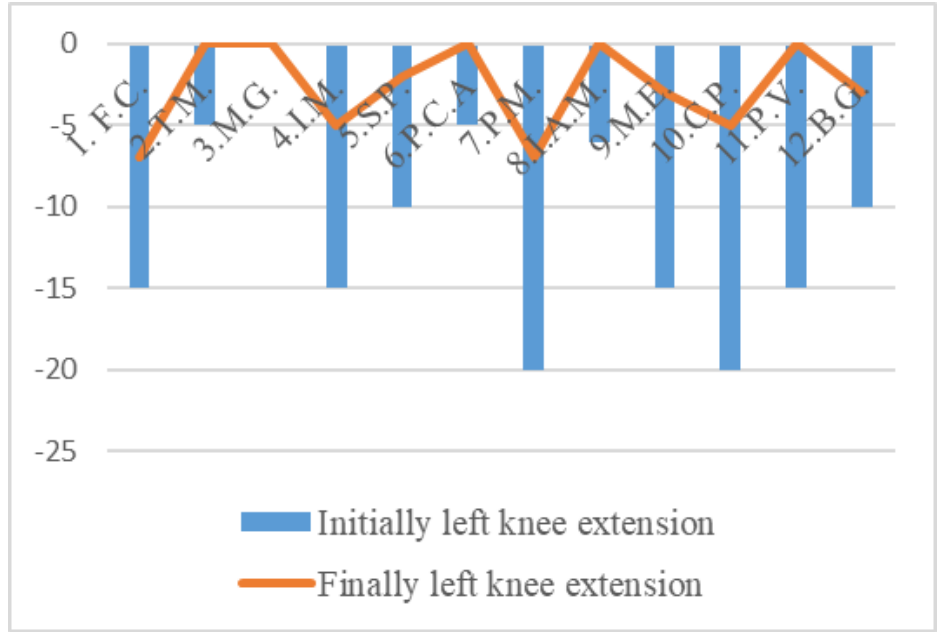

Fig.5 Increased extension to the left knee 


\section{References}

1. Bouillet R., Graver Ph.. L'Arthrose du genou: Etude pathogénique et traitement. ed. Acta Orthop Belgica; 1961.

2. Deninschi Aurel, Antonescu Dan. Gonartroza ed. Medicală; 1977.

3. Munteanu Constantin, Munteanu Diana, Hoteteu Mihail, Dogaru Gabriela Balneotherapy - medical, scientific, educational and economic relevance reflected by more than 250 articles published in Balneo Research Journal, Balneo Research Journal. 2019;10(3):174-203 Full Text DOI 10.12680/balneo.2019.257

4. Baciu C. Clement, Semiologia clinică a aparatului locomotor ed. Medicală; 1975.

5. Maquet G.J. Paul. Biomechanics of the knee ed. Springer-Verlag Berlin Heidelburg; 1984.

6. Moraru Gheorghe, Pâncotan Vasile. Recuperarea kinetică în reumatologie ed. Imprimeriei de Vest; 1999.

7. Crețu Antoaneta, Boboc Florin. Kinetoterapia în afectiunile reumatice. ed. A.N.E.F.S.; 2003.

8. Onu Ilie, Matei Daniela, Galaction Anca. Efficacy of intra-articular hyaluronic acid injections in the rehabilitation programme of Knee Osteoarthritis. Balneo Research Journal. 2019 September. 10(3): 225-230

9. Netter H. Frank. Atlas de anatomie umană, Ediția a V-a ed. Callisto; 2013

10. Papilian Victor. Anatomia omului, Ediția a Va Vol.I ed. Didactică și Pedagogică; 1974.

11. Marinescu Rodica. Genunchiul: Anatomie, biomecanică, traumatologie şi recuperare Ed. Fundaţiei Universitare "Dunărea de Jos"; 2008.

12. Albu Ion, Georgia Radu. Anatomie topografica Ediția a II-a ed. ALL MEDICALL; 1998.

13. Baciu C. Clement. Anatomia funcțională și biomecanica aparatului locomotor ed. SportTurism; 1977.

14. Munteanu Constantin, Munteanu Diana Healthy Aging, Balneo Research Journal. 2013;4(3):121-132, Full Text DOI 10.12680/balneo.2013.1051

15. Baciu C. Clement. Aparatul locomotor ed. Medicală; 1981.

16. Baciu C. Clement. Biomecanica genunchiului ed. pentru cultură fizică și sport; 1964.

17. Balint T. ,Diaconu I., Moise A., Evaluarea aparatului locomotor: bilanț articular, bilanț muscular, teste funcționale ed. Tehnopress; 2007.

18. Roşulescu Eugenia. Kinetoterapia în recuperarea afecţiunilor reumatologice ed. Universitaria Craiova; 2009.

19. Stroescu Ion. Recuperarea funcţională în practica reumatologică ed. Medicală; 1979.

20. Popescu Roxana. Ghid de evaluare clinică și funcțională în recuperarea medicală, Vol. I. ed. Medicală Universitară; 2004.

21. Sbenghe Tudor, Bazele teoretice și practice ale kinetoterapiei ed. Medicală; 1999.

22. Marcu Vasile, Mirela Dan. Kinetoterapie ed. Universității din Oradea; 2006.

23. Cordun Mariana. Kinetologia medicală ed. Axa; 1999.

24. Sbenghe Tudor. Kinesiologie Știința mișcări ed. Medicală; 2008.

25. Sbenghe Tudor. Kinetologie profilactică, terapeutică și de recuperare ed. Medicală; 1987.

26. Cristea Florentina. Metodologia recuperării kinetice al sindromului dureros lombar la persoanele de vârsta a II-a, teză de doctor în științe pedagogice; 2019. pag. 39-40

27. Caralicea-Mărculescu Gheorghe. Statistica pentru educație fizică și sport ed. Ager; 2005. 